\begin{tabular}{lrr}
\hline Volume 21 & Nomor 1, Januari 2020 & Halaman 49-58 \\
URL: https://jurnal.unej.ac.id/index.php/SEMIOTIKA/index & E-ISSN: 2599-3429 & P-ISSN: 1411-5948 \\
\hline
\end{tabular}

\title{
STRATEGI TINDAK TUTUR JURU BICARA TIM KAMPANYE NASIONAL DALAM ACARA "DUA ARAH" DI KOMPAS TV
}

\section{SPEECH ACT STRATEGY USED BY THE SPOKEPERSON OF NATIONAL CAMPAIGN TEAM ON KOMPAS TV "DUA ARAH"}

\author{
Ikromal Hasin $^{1}$, Akhmad Sofyan $^{2}$, Edy Hariyadi ${ }^{3} *$ \\ ${ }^{1}$ Alumni Fakultas Ilmu Budaya Universitas Jember \\ ${ }^{2,3}$ Fakultas Ilmu Budaya Universitas Jember \\ *Corresponding Author: edy.hariyadi@gmail.com \\ Informasi Artikel: \\ Dikirim: 17/7/2019; Direvisi: 10/10/2019; Diterima: 20/12/2019
}

\begin{abstract}
Presidential Election is a democratic party to elect new leaders. A spokesperson is needed to attract the public to choose the candidate pairs who compete to win the party. A spokesperson for TKN-Jokowi's National Campaign Team (Indonesian: Tim Kampanye Nasional) is one example of a spokesperson who carried out this task. This article aims to discuss the national campaign team's speech acts strategy in Kompas TV program entitled "Dua Arah". The researcher will categorize articulation carried out by the spokesperson of TKN into four types of speech works: persuasive, defending, attacking, and challenging. The data analysis method used analyses speech based on the specified categories in speech acts, presuppositions, implicatures, cooperative principles, and the principle of manners found in the address based on the context of the talk. The results showed that the spokesperson for the TKN placed persuasive action in the first position, fending effort in the second position, attacking movement in the third position, and challenging activities in the last part. Convincing story at the first position aims to attract the people's sympathy to choose Jokowi-Ma'ruf Amin with the most utterances telling Jokowi's government program's success. The challenging action in the last position contains a request to the spokesman of BPN-Prabowo's election campaign team (Indonesian: Badan Pemenangan Nasional) to do something and explain their statement in detail.
\end{abstract}

Keywords: presidential election, spokesperson, speeches, speech acts, Kompas TV

Abstrak

Pemilihan Presiden (Pilpres) merupakan pesta demokrasi untuk memilih pemimpin baru. Agar menjadi pihak yang menang dibutuhkan juru bicara untuk menarik minat masyarakat agar memilih pasangan calon (Paslon) yang berkompetisi. Juru bicara Tim Kampanye Nasional (TKN) merupakan salah satu contoh juru bicara yang mengemban tugas ini. Artikel ini bertujuan mendiskusikan strategi tindak tutur juru bicara tim kampanye nasional dalam acara "Dua Arah" di Kompas TV. Peneliti mengategorikan tuturan yang dilakukan juru bicara TKN menjadi empat jenis tindak tutur, yaitu tindak persuasif, tindak menangkis, tindak menyerang, dan tindak menantang. Metode analisis data yang digunakan adalah menganalisis tuturan berdasarkan kategori yang ditentukan berupa jenis tindak tutur, praanggapan, implikatur, prinsip kerja sama, dan prinsip sopan santun yang terdapat di dalam tuturan berdasarkan konteks ketika tuturan terjadi. Hasil 
penelitian menunjukkan bahwa juru bicara TKN menempatkan tindak persuasif pada posisi pertama, tindak menangkis pada posisi kedua, tindak menyerang pada posisi ketiga, dan tindak menantang pada posisi terakhir. Tindak persuasif yang berada pada posisi pertama bertujuan untuk menarik simpati masyarakat agar memilih Jokowi-Ma'ruf Amin paling banyak berisi tuturan memberitahukan keberhasilan program pemerintah Jokowi. Sementara itu, tindak menantang yang berada pada posisi terakhir berisi permintaan kepada juru bicara Badan Pemenangan Nasional (BPN) untuk melakukan sesuatu dan menjelaskan pernyataan mereka (BPN) secara detail.

Kata kunci: pemilihan presiden, juru bicara, tuturan, tindak tutur, Kompas TV

\section{PENDAHULUAN}

Bahasa merupakan sarana yang paling utama dan vital untuk memenuhi kebutuhan manusia dalam menyampaikan ide, gagasan, pikiran, maksud, dan realitas (Sumarlam, 2003:1). Habermas (dalam Latif dan Ibrahim, ed., 1996:45) mengatakan bahwa "language is a medium of consolidation and domination of power". Bahasa adalah sarana konsolidasi dan dominasi kekuatan. Dari pengertian di atas dapat disimpulkan bahwa bahasa memiliki pelbagai manfaat. Salah satu manfaat penggunaan bahasa dalam menyampaikan gagasan adalah penggunaan bahasa oleh politikus.

Bahasa yang digunakan oleh politikus berbeda dengan bahasa pada umumnya yang dipakai oleh masyarakat. Perbedaan pemakaian bahasa tersebut karena para politikus ingin menyembunyikan tujuan sebenarnya dari tuturan yang digunakannya. Fenomena ini di antaranya terlihat pada acara "Dua Arah" di Kompas TV. Dalam acara "Dua Arah", juru bicara Tim Kampanye Nasional (TKN) yang merupakan tim kampanye pasangan calon (Paslon) 01 Jokowi-Ma'ruf Amin menggunakan tuturannya untuk berkompetisi dengan juru bicara Badan Pemenangan Nasional (BPN) yang merupakan tim kampanye pasangan calon (Paslon) 02 Prabowo-Sandiaga Uno.

Terdapat beberapa penelitian yang mengkaji bahasa dalam politik dan tindak tutur berkaitan dengan pemakaian lokusi, ilokusi, dan perlokusinya. Penelitian yang membahas bahasa dalam politik di antaranya, penelitian yang dilakukan oleh Sofyan (2001a) dengan judul "Pengaruh Manipulasi Fungsi Bahasa terhadap Kondisi Bahasa Indonesia (Pendayagunaan Bahasa Indonesia sebagai Sarana Peredam Gejolak Sosial di Era Orde Baru)". Penelitian ini membahas pergolakan sosio-politis di era Orde Baru (Orba) yang tercermin dalam pemakaian bahasa. Kesimpulan penelitian ini adalah pihak politisi memanipulasi fungsi bahasa dengan cara menciptakan beragam eufimisme, mengaburkan makna kata, dan melakukan peniruan gaya berbahasa orang yang paling berwibawa dan paling berkuasa.

Penelitian kedua masih dilakukan oleh Sofyan (2001b) dengan judul "Bahasa dan Realitas Pergolakan Sosio-Politis: Kasus Bahasa Indonesia pada Era Orde Baru, Pergerakan Reformasi, dan Era Gus Dur". Penelitian ini membahas pergolakan sosio-politis yang memantul dalam bahasa Indonesia. Pergolakan ini memunculkan perbedaan bahasa Indonesia pada ketiga sistem pemerintahan. Kesimpulan penelitian ini adalah pada era Orba banyak dijumpai eufimisme, banyak kata bermakna kabur, akhiran -kan diucapkan -ken, penggunaan kata daripada yang tidak pada tempatnya, dan sering dijumpai plesetan dan penyelewengan 
konsep. Pada era Pergerakan Reformasi 1998 terjadi "perang simbol" antara pemerintah dan rakyat. Pada era Gus Dur penggunaan eufimisme sangat dihindari oleh pemerintah, banyak dijumpai plesetan, perlawanan simbol dilakukan oleh individu dan kelembagaan, dan terjadi "perang simbol" yang berupa penggunaan simbol yang sama tetapi alasannya berlawanan.

Penelitian ketiga dilakukan oleh Firmonasari (2007) dengan judul "Wacana Politik Nicolas Sarkozy: Analisis Psikostruktural Lacanian". Penelitian ini membahas diskursus yang dilakukan oleh Presiden Perancis Nicolas Sarkozy saat melakukan kampanye sebelum kemenangan dan pelantikannya. Sarkozy menggunakan retorika kampanye menarik yang membuatnya dapat terpilih sebagai Presiden Perancis 2007. Dalam bentuk retorika kampanye politiknya, Sarkozy berusaha memberikan rasa aman kepada rakyat Perancis yang khawatir atas kehadiran para imigran. Kesimpulan penelitian ini adalah sebagai upaya untuk menarik pengikutnya, wacana politik Sarkozy bersifat memunculkan atau membangkitkan hasrat narsistik pasif dan memuaskan hasrat narsistik pasif. Pemunculan hasrat narsistik dengan menggunakan kelemahan-kelemahan pribadi, membangkitkan "ingatan publik", serta memberikan rasa aman kepada warganya. Pemuasan hasrat narsistik pasif dilakukan dengan cara berusaha melepaskan diri dari 'kecemasan' dengan menawarkan argumentasi yang berpihak pada rakyat, misalnya pengurangan pajak. Selain itu, perangkulan partai kiri dan kanan juga digunakan sebagai salah satu cara untuk pemuasan hasrat narsistik pasif. Hasrathasrat dalam wacana tersebut dimanifestasikan dengan penanda kolektif, metonimia dan metafora.

Penelitian keempat dilakukan oleh Revia (2016) dengan judul "Tindak Tutur Ekspresif dalam Acara Talkshow Mata Najwa di Metro TV". Penelitian ini membahas tindak tutur ekspresif yang diucapkan oleh para pewara dan narasumber yang ada di acara Talkshow Mata Najwa di Metro TV. Jenis tindak tutur yang paling banyak ditemukan adalah tindak tutur ekspresif berterima kasih dan tindak tutur ekspresif memberi selamat. Alasan ucapan terima kasih dan memberi selamat yang paling banyak ditemukan karena pewara lebih banyak menggunakan ucapan terima kasih dan ucapan selamat kepada narasumber maupun penonton Mata Najwa. Selain itu, pewara mengucapkan terima kasih karena ungkapan perasaan narasumber telah bersedia hadir dan menjawab pertanyaan dari pewara. Simpulan penelitian ini adalah dalam tuturan yang digunakan sehari-hari tanda disadari mengandung tindak tutur khususnya tindak tutur ekspresif.

Penelitian kelima dilakukan oleh Putri (2018) dengan judul "Tindak Tutur Persuasif Debat Calon Gubernur DKI Jakarta 2018 Putaran Pertama pada Media Televisi”. Penelitian ini membahas tentang cara membujuk yang digunakan pasangan calon agar pemilih atau masyarakat Jakarta khususnya tertarik dan memilih paslon yang sedang berkampanye. Kesimpulan penelitian ini adalah dalam debat calon Gubernur Jakarta 2017 terdapat modus persuasif dalam bentuk kalimat deklaratif, interogatif dan imperatif. Teknik persuasif yang digunakan dalam berdebat yaitu membangun citra positif, perhatian (empati), dan mengunggulkan progam kerja, menunjukkan hasil kerja, dan memberikan janji.

Berbeda dengan kelima penelitian di atas, penelitian tindak tutur ini merupakan penelitian baru yang belum pernah dilakukan, karena sebelumnya belum pernah ada penelitian yang mendeskripsikan jenis tindak tutur dari juru bicara partai politik terutama juru 
bicara dari Tim Kampanye Nasional yang mendukung pasangan calon Jokowi-Ma'ruf Amin dan terbentuk pada tahun 2018. Selain mendeskripsikan jenis tindak tutur, penelitian ini juga menjelaskan tujuan tindak tutur dari juru bicara Tim Kampanye Nasional itu dikeluarkan.

\section{METODE}

Penelitian ini menggunakan tiga tahapan, yaitu: 1) penyediaan data, 2) analisis data, 3) pemaparan hasil analisis data. Metode yang digunakan untuk penyediaan data adalah metode simak, dan teknik catat. Analisis data yang digunakan yaitu menganalisis tindak tutur berdasarkan kategori yang telah ditentukan dan disertai analisis praanggapan, implikatur, prinsip kerja sama, dan prinsip sopan santun. Pemaparan hasil analisis data menggunakan penyajian informal yaitu memaparkan hasil analisis dengan kata-kata biasa tanpa menggunakan rumus tanda-tanda atau lambang-lambang.

\section{HASIL DAN PEMBAHASAN}

Pada pertuturan dalam video acara "Dua Arah" terdapat tuturan yang termasuk tindak persuasif. Juru bicara Tim Kampanye Nasional menggunakan tuturan ini untuk mencapai tujuan yang diinginkan. Juru bicara Tim Kampanye Nasional menggunakan tindak persuasif untuk mengajak dan meyakinkan masyarakat untuk memilih paslon Jokowi-Ma'ruf Amin. Penggunaan tindak persuasif Tim Kampanye Nasional diuraikan sebagai berikut.

Data (1).

Konteks: Dialog ini terjadi di video acara "Dua Arah" Kompas TV tanggal 24 September 2018 dengan judul "Siapa di Hati Milenial?" pada menit 11:23-11:53. Acara tersebut dihadiri oleh perwakilan juru bicara TKN Lathifa Al Anshori dan Dedek Prayudi sedangkan juru bicara BPN diwakili oleh Jansen Sitindaon dan Nydia Hary dengan pembawa acara Cindy Sistyarani. Pihak yang terlibat dalam dialog adalah pembawa acara Cindy Sistyarani (CS) dengan juru bicara TKN Lathifa Al Anshori (LA). Maksud tuturan dalam dialog yaitu LA menjelaskan kepada CS tentang pencapaian yang telah dilakukan oleh pemerintahan Jokowi. Sebelumnya pemerintahan Jokowi untuk menepati janji-janjinya sejak masa kampanye 2014 telah mengeluarkan Kartu Indonesia Sehat (KIS), Kartu Indonesia Pintar (KIP), Kartu Keluarga Sejahtera, dan Kartu Simpanan Keluarga Sejahtera (KSKS) yang diharapkan dapat menyejahterakan masyarakat.

Percakapan:

LA (1.a) : [...] Pak Jokowi membuka secara lebar, beliau open minded sama seperti anak-anak muda, supaya apa yang ada di luar, kemajuankemajuan yang sudah ada di negara-negara lain itu sudah bisa dinikmati oleh generasi-generasi muda kita.

CS (1.b) : Jadi programnya menurut Mbak Lathifa sudah?

LA (1.c) : Tentu saja sudah dan ini baru saja program yang mengarah ke usaha. Belum lagi dengan jaminan-jaminan kesehatan dan juga akses pendidikan. Bayangkan saja berapa banyak dana yang digelontorkan untuk beasiswa mahasiswa ke luar negeri. 
Data (1) merupakan tindak persuasif dibuktikan dengan analisis berikut. Tuturan (1.a) dan (1.c) merupakan tindakan memuji keberhasilan yang telah dicapai Jokowi yang merupakan paslon yang didukung. Sasaran pujian ditujukan kepada Jokowi yang menjadi Presiden Indonesia periode 2014-2019 dan calon presiden 01 Pemilu 2019. Tuturan (1.a) merupakan pujian yang ditandai dengan kalimat kemajuan-kemajuan sudah ada di negaranegara lain itu sudah bisa dinikmati oleh generasi-generasi muda kita. Tuturan (1.c) juga merupakan pujian yang ditandai dengan kalimat jaminan-jaminan kesehatan dan juga akses pendidikan dan dana yang digelontorkan untuk beasiswa mahasiswa ke luar negeri. Melalui tuturan (1.a) dan (1.c) penutur menaikkan citra diri Jokowi dengan memberitahu masyarakat bahwa pemerintahan Jokowi telah berhasil melaksanakan program-program di bidang teknologi, kesehatan, dan pendidikan. Implikatur dari tuturan (1.a) dan (1.c) di atas adalah Jokowi telah sukses menjalankan program-program selama masa pemerintahannya. Tuturan (1.c) merupakan tuturan yang mentaati prinsip kerja sama pada maksim relevansi. Hal ini dapat dibuktikan dengan adanya keterkaitan dengan tuturan (1.a) dan tuturan (1.b) yang samasama membahas tentang program. Tuturan (1.a) dan (1.c) merupakan tuturan yang melanggar prinsip sopan santun pada maksim kedermawanan. Hal ini dapat dibuktikan dengan penutur yang menaikkan citra diri Jokowi sehingga penutur menjadi diuntungkan karena telah menjalankan tugasnya. Tuturan (1.a) dan (1.c) yang memuji Jokowi juga dapat dikategorikan sebagai tindak ekspresif dari Searle. Jadi sesuai dengan penjabaran di atas dapat disimpulkan bahwa tuturan (1.a) dan (1.c) merupakan tindak persuasif.

Pada pertuturan dalam video acara "Dua Arah" terdapat tuturan yang termasuk tindak menangkis. Juru bicara Tim Kampanye Nasional menggunakan tuturan ini untuk menangkis tuturan dari juru bicara Badan Pemenangan Nasional. Juru bicara Tim Kampanye Nasional menggunakan tindak menangkis untuk mengelak, menghindar, menegatifkan tuturan dari juru bicara Badan Pemenangan Nasional. Penggunaan tindak menangkis Tim Kampanye Nasional akan diuraikan sebagai berikut.

Data (2).

Konteks: Dialog ini terjadi di video acara "Dua Arah" Kompas TV tanggal 8 Oktober 2018 dengan judul Siapa di Balik Drama Ratna? pada menit 36:15-38:14. Acara tersebut dihadiri oleh perwakilan juru bicara TKN Budiman Sudjatmiko dan Dini Shanti Purwono sedangkan juru bicara BPN diwakilkan oleh Andre Rosiade dan Faldo Maldini dengan pembawa acara Cindy Sistyarani. Pihak yang terlibat dalam dialog adalah pembawa acara Cindy Sistyarani (CS) dengan juru bicara TKN Dini Shanti Purwono (DS). Maksud tuturan dalam dialog yaitu CS mengulangi pernyataan Andre Rosiade tentang koalisi Jokowi yang mengambil keuntungan dari kasus hoaks Ratna Sarumpaet. Kemudian DS menangkis serangan tersebut dengan menanyakan pihak pertama yang menyebar hoaks Ratna Sarumpaet. Sebelumnya Oktober 2018 Ratna Sarumpaet yang tergabung ke dalam timses Prabowo-Sandi menyebarkan berita hoaks dirinya dianiaya oleh sejumlah pria tidak dikenal. Kemudian Prabowo dan timsesnya membenarkan berita penganiayaan itu. Polisi yang mendapat laporan penganiayaan tersebut melakukan penyelidikan dan menyanggah Ratna Sarumpaet mengalami penganiayaan. Ratna Sarumpaet kemudian menggelar konferensi pers dan mengaku telah berbohong. 
Percakapan:

AR (2.a) : Kita lihat bagaimana setiap hari Raja Juli Antoni lalu Mas Budiman dan lain-lain, tiap hari menggoreng ada yang bilang supaya Pak Prabowo didiskualifikasi, lalu ada ketua umum partai mimpi di siang bolong bilang berbondong-bondong pendukung Pak Prabowo pindah. Kadang orang mimpi nglindur gitu, mimpi di siang bolong. Jadi intinya mereka terus menggoreng. Saya ingin menyampaikan mari kita objektif bukan hanya Pak Prabowo yang salah, Pak Jokowi pun juga pernah salah bahkan menandatangani Perpres tanpa baca loh.

CS (2.b) : Tapi soal tadi disebutkan oleh Bang Andre ini digoreng terus dimanfaatkan oleh koalisi Joko Widodo dan juga Ma'ruf Amin untuk mengambil keuntungan dari kasus ini, Mbak Dini.

DS (2.c) : (a) Nah kalau mau ngomong goreng ya, saya justru bingung nih Mbak Cindy. (b) Siapa yang pertama kali bikin pers konpers memberitakan hal yang sifatnya pribadi yang sudah dijelaskan Mas Budiman tadi, membawa ini ke ranah publik. (c) Pertanyaan saya siapa yang pertama kali membawa ini ke ranah publik? (d) Pak Prabowo dan timnya kan. (e) Siapa yang nge-twitt, ya kan, dengan apa namanya, bahwa oh ya ada penganiayaan. Siapa? (f) Jadi siapa sebetulnya yang mau menggoreng isu ini, gitu kan. (g) Kemudian dilempar kepada publik. Siapa?

Data (2) merupakan tindak menangkis dibuktikan dengan analisis berikut. Tuturan (2.a) merupakan tindak menyerang yang dilakukan juru bicara BPN (Andre Rosiade) dan diulang oleh penutur. Tuturan (2.c) merupakan bantahan yang menegasikan tuturan (2.a). Melalui tuturan (2.c) penutur menurunkan citra diri Prabowo dengan memberitahukan pihak yang pertama kali menyebarkan hoaks Ratna Sarumpaet adalah pihak Prabowo. Sasaran serangan ditujukan kepada paslon lawan (Prabowo Subianto) yang menjadi Calon Presiden 02 Pemilu 2019. Penutur menggunakan kalimat Pak Prabowo dan timnya kan yang didukung oleh fakta kalimat (b), (c), (e), (f) yang dapat dikategorikan sebagai tindak menangkis jika dihubungkan dengan kalimat dimanfaatkan oleh koalisi Joko Widodo dan juga Ma'ruf Amin untuk mengambil keuntungan. Praanggapan dalam dialog di atas adalah penutur dan lawan tutur sama-sama mengetahui bahwa Ratna Sarumpaet telah menyebarkan hoaks bahwa dirinya dianiaya dan Prabowo serta timsesnya percaya pada hoaks itu sebelum meminta maaf kepada publik. Implikatur dari tuturan di atas adalah Prabowo yang memulai konferensi pers ingin mengambil keuntungan dari kasus Ratna. Tuturan (2.c) merupakan tuturan yang mentaati prinsip kerja sama pada maksim relevansi. Hal ini dapat dibuktikan dengan adanya keterkaitan dengan tuturan (2.a). Tuturan (2.c) merupakan tuturan yang melanggar prinsip sopan santun pada maksim kebijaksanaan. Hal ini dapat dibuktikan dengan penutur yang menurunkan citra diri Prabowo sehingga lawan tutur menjadi dirugikan karena tidak menjalankan tugasnya. Tuturan (2.c) yang menyalahkan Prabowo juga dapat dikategorikan sebagai tindak ekspresif dari Searle. Jadi sesuai dengan penjabaran di atas dapat disimpulkan bahwa tuturan (2.c) merupakan tindak menangkis.

Pada pertuturan dalam video acara "Dua Arah" terdapat tuturan yang termasuk tindak menyerang. Juru bicara Tim Kampanye Nasional menggunakan tuturan ini untuk mencapai tujuan yang diinginkan. Juru bicara Tim Kampanye Nasional menggunakan tindak menyerang 
untuk mengajak dan meyakinkan masyarakat untuk tidak memilih paslon Prabowo-Sandiaga Uno. Penggunaan tindak menyerang Tim Kampanye Nasional akan diuraikan sebagai berikut.

Data (3).

Konteks: Dialog ini terjadi di video acara "Dua Arah" Kompas TV tanggal 3 Desember 2018 dengan judul Berantas Korupsi, Lain di Bibir Lain di Hati? pada menit 05:15-05:55. Acara tersebut dihadiri oleh perwakilan juru bicara TKN Masinton Pasaribu dan Rian Ernest sedangkan juru bicara BPN diwakilkan oleh Ferry Juliantono dan Vasco Ruseimy dengan pembawa acara Cindy Sistyarani. Pihak yang terlibat dalam dialog adalah pembawa acara Cindy Sistyarani (CS) dengan juru bicara TKN Masinton Pasaribu (MP). Maksud tuturan dalam dialog yaitu CS menanyakan pendapat MP tentang tanggapannya perihal pernyataan Prabowo tentang korupsi seperti kanker stadium 4. Kemudian MP menjawab pertanyaan CS dengan mengibaratkan pernyataan Prabowo seperti pepesan kosong tanpa solusi. Sebelumnya Prabowo mengeluarkan pernyataan korupsi di Indonesia seperti kanker stadium empat. Hal itu disampaikan Prabowo saat berbicara pada acara "The World in 2019 Gala Dinner" yang diselenggarakan The Economist di Hotel Grand Hyatt Singapura.

Percakapan:

CS (3.a) : Apa tanggapan dari kubu petahana Bang Masinton kanker stadium 4 korupsi? Ini PDI juga akhirnya bereaksi cukup keras soal ini.

MP (3.b) : Bagi saya apa yang disampaikan Pak Prabowo ini sama dengan pernyataan-pernyataan sebelumnya pepesan kosong.

CS (3.c) : Kenapa?

MP (3.d) : Kenapa dia pepesan kosong karena memang tidak memberikan apapun. Dia jelaskan ini begini, ini begitu sensasinya muncul tapi sebagai seorang calon pemimpin, calon presiden harusnya dia memberikan solusi alternatifnya apa.

Data (3) merupakan tindak menyerang dibuktikan dengan analisis berikut. Tuturan (3.a) merupakan tindakan bertanya. Tuturan (3.b) dan (3.d) merupakan tindakan menyerang paslon lawan (Prabowo). Melalui tuturan (3.d) penutur menurunkan citra diri Prabowo dengan memberitahukan hal yang disampaikan Prabowo tidak memberikan solusi sehingga diumpamakan seperti pepesan kosong. Sasaran serangan ditujukan kepada paslon lawan (Prabowo) yang menjadi Calon Presiden 02 Pemilu 2019. Penutur menggunakan kalimat pepesan kosong karena memang tidak memberikan apapun yang dapat dikategorikan sebagai tindak menyerang. Menurut KBBI pepesan adalah lauk yang dibuat dari ikan yang dirempahi dan dibungkus dengan daun pisang, kemudian dipanggang atau dikukus. Pepesan kosong sama dengan tidak memiliki isi atau hanya bungkusan. Praanggapan dalam dialog di atas adalah penutur dan lawan tutur sama-sama mengetahui bahwa Prabowo mengeluarkan pernyataan korupsi di Indonesia seperti kanker stadium empat. Implikatur dari tuturan di atas adalah ucapan Prabowo hanya mencari sensasi tanpa memberikan solusi. Tuturan (3.d) merupakan tuturan yang mentaati prinsip kerja sama pada maksim relevansi. Hal ini dapat dibuktikan dengan adanya keterkaitan dengan tuturan (3.a), (3.b) dan (3.c) yang membahas 
pernyataan Prabowo. Tuturan (3.d) merupakan tuturan yang melanggar prinsip sopan santun pada maksim kedermawanan. Hal ini dapat dibuktikan dengan penutur yang menurunkan citra diri Prabowo sehingga penutur menjadi diuntungkan karena telah menjalankan tugasnya. Tuturan (3.d) yang menyindir Prabowo juga dapat dikategorikan sebagai tindak ekspresif dari Searle. Jadi sesuai dengan penjabaran di atas dapat disimpulkan bahwa tuturan (3.d) merupakan tindak menyerang.

Pada pertuturan dalam video acara "Dua Arah" terdapat tuturan yang termasuk tindak menantang. Juru bicara Tim Kampanye Nasional menggunakan tuturan ini untuk mencapai tujuan yang diinginkan. Juru bicara Tim Kampanye Nasional menggunakan tindak menantang untuk mengajak dan menyuruh juru bicara Badan Pemenangan Nasional melakukan sesuatu. Penggunaan tindak menantang Tim Kampanye Nasional akan diuraikan sebagai berikut.

Konteks: Dialog ini terjadi di video acara "Dua Arah" Kompas TV tanggal 12 November 2018 dengan judul "Siapa Berpolitik Genderuwo?" pada menit 18:0318:28. Acara tersebut dihadiri oleh perwakilan juru bicara TKN Deddy Sitorus dan Tsamara Amany sedangkan juru bicara BPN diwakilkan oleh Ferdinand Hutahaen dan Habiburokhman dengan pembawa acara Frisca Clarissa. Pihak yang terlibat dalam dialog adalah juru bicara BPN Ferdinand Hutahaen (FH) dengan juru bicara TKN Tsamara Amany (TA). Maksud tuturan dalam dialog yaitu FH menjelaskan buruh asing memang ada sejak zaman SBY tetapi berupa buruh ahli. Kemudian TA membalas pernyataan FH dengan menantang FH menunjukkan lokasi buruh kasar yang dimaksud FH. Sebelumnya pada era pemerintahan Jokowi telah menyebar berita bahwa banyak tenaga kerja asing (TKA) yang tidak memiliki keahlian masuk ke Indonesia. TKA tersebut sebagian besar berasal dari Cina.

Percakapan:

FH (4.a) : Tsamara tadi bilang dulu sejak zaman SBY sudah ada 70.000-an, betul itu. Tetapi tenaga kerja asing itu bukan buruh kasar yang kerjanya ngaduk semen seperti sekarang yang kita temukan. Sekarang ini kita temukan buruh asing yang bukan teknisi-teknisi yang memang membutuhkan keahlian khusus.

TA (4.b) : Di mana itu Bang? Di mana itu lokasinya? Di mana tolong tunjukkan data dan lokasinya secara jelas di mana agar tidak jadi fitnah, agar tidak jadi politik genderuwo mohon tunjukkan lokasinya di mana!

Data (4) merupakan tindak menantang dibuktikan dengan analisis berikut. Tuturan (4.a) merupakan tindakan memberitahukan adanya tenaga kerja asing yang menjadi buruh kasar. Tuturan (4.b) merupakan tantangan kepada juru bicara BPN (Ferdinand Hutahaen). Melalui tuturan (4.b) penutur menantang lawan tutur (Ferdinand Hutahaen) untuk memberitahukan lokasi tenaga asing tersebut. Sasaran tantangan ditujukan kepada lawan tutur (Ferdinand Hutahaen) yang menjadi juru bicara BPN. Penutur menggunakan kalimat tolong tunjukkan data dan lokasinya yang dapat dikategorikan sebagai tindak menantang. Tuturan (4.b) merupakan tuturan yang mentaati prinsip kerja sama pada maksim relevansi. Hal ini dapat dibuktikan dengan adanya keterkaitan dengan tuturan (4.a) yang membahas tenaga kerja asing. Tuturan (4.b) merupakan tuturan yang melanggar prinsip sopan santun pada maksim 
pemufakatan. Hal ini dapat dibuktikan dengan penutur yang tidak menyetujui tuturan (4.a). Tuturan (4.b) yang meminta lawan tutur menjelaskan sesuatu juga dapat dikategorikan sebagai tindak direktif dari Searle. Jadi sesuai dengan penjabaran di atas dapat disimpulkan bahwa tuturan (4.b) merupakan tindak menantang.

\section{SIMPULAN}

Berdasarkan penelitian dapat disimpulkan bahwa tindak tutur juru bicara Tim Kampanye Nasional dalam acara "Dua Arah" di Kompas TV dapat dikategorikan ke dalam empat jenis tindak tutur yaitu tindak persuasif, tindak menangkis, tindak menyerang dan tindak menantang. Tuturan tersebut ditempuh menggunakan cara-cara tertentu.

Dalam penelitian ini ditemukan tindak persuasif juru bicara Tim Kampanye Nasional dilakukan dengan dua cara yaitu mengatakan keberhasilan program Jokowi; dan mengatakan Jokowi peduli kepada masyarakat. Tindak persuasif dapat tercapai jika penutur melanggar prinsip sopan santun pada maksim kedermawanan. Pelanggaran ini terjadi jika penutur menaikkan citra diri paslonnya dengan memuji sehingga penutur menjadi diuntungkan karena telah menjalankan tugasnya.

Tindak menangkis juru bicara Tim Kampanye Nasional dilakukan dengan empat cara yaitu mengatakan sindiran kepada Prabowo dan timsesnya; mengatakan keberhasilan program Jokowi; mengatakan Prabowo dan timsesnya mengucapkan kebohongan; dan mengatakan Jokowi peduli kepada masyarakat. Tindak menangkis diawali dengan lawan tutur yang melakukan tindak menyerang kemudian penutur membalas tindak menyerang tersebut. Tindak menangkis dapat tercapai jika penutur melanggar prinsip sopan santun pada maksim kebijaksanaan atau maksim kedermawanan. Pelanggaran maksim kebijaksanaan jika penutur menurunkan citra diri paslon lawan sehingga lawan tutur menjadi dirugikan karena tidak menjalankan tugasnya. Pelanggaran maksim kedermawanan jika penutur mempertahankan citra diri paslonnya dengan memuji sehingga penutur menjadi diuntungkan karena telah menjalankan tugasnya.

Tindak menyerang juru bicara Tim Kampanye Nasional dilakukan dengan dua cara yaitu mengatakan sindiran kepada Prabowo dan timsesnya; dan mengatakan kegagalan program Sandiaga Uno. Tindak menyerang dapat tercapai jika penutur melanggar prinsip sopan santun pada maksim kedermawanan. Pelanggaran ini terjadi jika penutur menurunkan citra diri paslon lawan sehingga penutur menjadi diuntungkan karena telah menjalankan tugasnya.

Tindak menantang juru bicara Tim Kampanye Nasional dilakukan dengan dua cara yaitu meminta juru bicara Badan Pemenangan Nasional melakukan sesuatu; dan meminta juru bicara Badan Pemenangan Nasional menjelaskan dengan detail. Tindak menantang dapat tercapai jika penutur melanggar prinsip kerja sama pada maksim permufakatan dengan cara tidak menyetujui tuturan lawan tutur. Tindak menantang menandakan bahwa penutur dan lawan tutur memiliki ketidaksesuaian atau perbedaan pendapat.

Penelitian ini membuktikan bahwa juru bicara Tim Kampanye Nasional menempatkan tindak persuasif pada posisi pertama, kemudian tindak menangkis pada posisi kedua, tindak menyerang pada posisi ketiga, dan tindak menantang pada posisi terakhir. Tuturan juru bicara 
Tim Kampanye Nasional yang paling banyak digunakan adalah tuturan keberhasilan program pemerintah Jokowi. Hal ini dibuktikan dengan banyaknya data tuturan keberhasilan program yang terdapat pada tindak persuasif (mayoritas) dan tindak menangkis (minoritas).

\section{DAFTAR PUSTAKA}

Firmonasari, A. 2007. "Wacana Politik Nicolas Sarkozy: Analisis Psikostruktural Lacanian". Humaniora, 19 (3):274-283.

Latif, Y. dan Ibrahim, I.S. (ed.) 1996. Bahasa dan Kekuasaan: Politik Wacana di Panggung Orde Baru. Bandung: Mizan.

Putri, R. 2018. “Tindak Tutur Persuasif Debat Calon Gubernur DKI Jakarta 2018 Putaran Pertama pada Media Televisi”. Simki-Pedagogja, 02 (06). Kediri: Universitas Nusantara PGRI Kediri.

Revia, M. 2016. "Tindak Tutur Ekspresif dalam Acara Talkshow Mata Najwa di Metro TV". http://jim.stkip-pgri-sumbar.ac.id/jurnal/view/ZZ7X (diakses pada 17 Maret 2019). Padang: STKIP PGRI Sumatra Barat.

Sofyan, A. 2001a. "Pengaruh Manipulasi Fungsi Bahasa terhadap Kondisi Bahasa Indonesia (Pendayagunaan Bahasa Indonesia sebagai Sarana Peredam Gejolak Sosial di Era Orde Baru)". Jurnal Ilmu Bahasa dan Sastra, 1 (1). Jember: Fakultas Sastra Universitas Jember.

Sofyan, A. 2001b. "Bahasa dan Realitas Pergolakan Sosio-Politis: Kasus Bahasa Indonesia pada Era Orde Baru, Pergerakan Reformasi, dan Era Gus Dur”. Jurnal Ilmu Bahasa dan Sastra, 1 (2). Jember: Fakultas Sastra Universitas Jember.

Sumarlam. 2003. Teori dan Praktik Analisis Wacana. Surakarta: Pustaka Cakra. 